\title{
29. PHYSICAL PROPERTIES, SYNTHETIC SEISMOGRAMS, AND SEISMIC REFLECTIONS: CORRELATIONS AT DEEP SEA DRILLING PROJECT SITE 534, BLAKE-BAHAMA BASIN 1
}

\author{
Thomas H. Shipley, ${ }^{2}$ Scripps Institution of Oceanography, University of California, San Diego, La Jolla, California
}

\begin{abstract}
Laboratory measurements on sediment samples and density well logs run at DSDP Site 534 in the Blake-Bahama Basin were used to establish an in situ velocity and density structure. Synthetic seismograms were generated for comparison to reprocessed seismic reflection data in the vicinity of the Site. Uncertainties in the relative positions of the hole and seismic reflection data, velocity corrections, and the composition of the unrecovered section were evaluated. In light of the errors and compressed section, no unique correlation of the seismic reflection data to the drill hole is completely defensible either in this chapter or elsewhere.

The preferred correlation resulting from this exercise is as follows, with the Site 534 report correlation shown in parentheses where different. Horizon $\beta^{\prime}, 887 \mathrm{~m}$; Horizon $\beta, 950 \mathrm{~m}$ (975 m); Horizon $C^{\prime}, 1202 \mathrm{~m}(1250 \mathrm{~m})$; Horizon C, $1268 \mathrm{~m}(1340 \mathrm{~m})$; Horizon D', $1342 \mathrm{~m}$ (1432 m); Horizon D, $1550 \mathrm{~m}(1552 \mathrm{~m})$.

The major differences in these correlations arise from the use of slightly different velocities and hole location relative to the seismic profiles. The Site 534 report results rely on hole placement on a basement flank, whereas in this chapter we locate it within a basement depression still within the uncertainty of the navigation. The Site 534 report also uses drilling rates, CDP velocity analyses, sonobuoy data, and previous similar drilling correlation methods used at Site 391, along with other geologic considerations in arriving at differing results. Although the correlation method used in this investigation is more objective and the hole location uncertainties better defined, in order to have confidence in any results we will require drilling in areas where reflections are either more widely spaced or where we have better vertical velocity control in the hole.
\end{abstract}

\section{INTRODUCTION}

Some of the first sediments deposited in the newly formed North Atlantic were sampled in the Blake-Bahama Basin at Deep Sea Drilling Site 534 (Fig. 1). Because Site 534 was successful in drilling $1666 \mathrm{~m}$ to reach middle Callovian sediments overlying volcanic basement, it is destined to be one cornerstone in deciphering the early phases of rifting and spreading of the North Atlantic. Extrapolation of the drilling results to the regional geology of this continental margin will rely on correlation to the established seismic-stratigraphic framework-the purpose of this investigation.

Rather significant improvements in seismic reflection data collection and analysis methods have resulted in a comprehensive deep-sea seismic-stratigraphic framework for this area (Bryan et al., 1980; Buffler et al., 1978; Jansa et al., 1979; Klitgord and Grow, 1980; Sheridan et al., 1974, 1978, 1979, and this volume; Shipley et al., 1978; Shipley and Watkins, 1978; Tucholke, 1979; Tucholke and Mountain, 1979). Although we will not dwell on this stratigraphic framework, because it is covered in other chapters in this volume, a brief summary of the seismic- and lithostratigraphy and age relationships will be useful. The basic seismic reflections of regional extent so far identified in this area are designated $\mathrm{M}, \mathrm{X}, \mathrm{A}, \beta, \mathrm{C}$ (or $\left.\mathrm{J}_{1}\right), \mathrm{D}\left(\right.$ or $\mathrm{J}_{2}$ ), and $\mathrm{J}_{3}$. At Site 534 we drilled through the section equivalent to $\mathrm{A}, \beta, \mathrm{C}$, and $\mathrm{D}$.

\footnotetext{
${ }^{1}$ Sheridan, R. E., Gradstein, F. M., et al., Init. Repts. DSDP, 76: Washington (U.S Govt, Printing Office.

2 Present address: University of Texas, Institute of Geophysics, Austin, Texas.
}

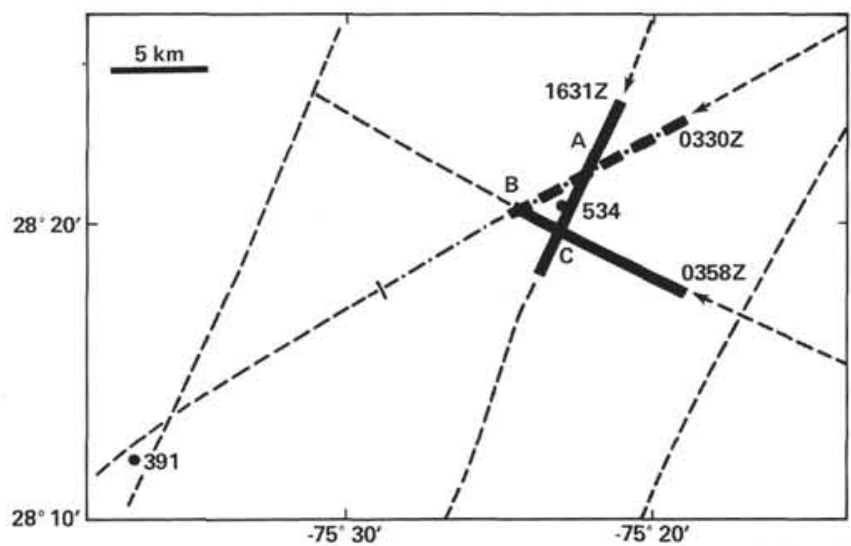

Figure 1. Chart showing location of DSDP Sites 391 and 534. (Tracks are Lamont-Doherty Geological Observatory [LDGO] 24-channel seismic reflection lines. Thick lines represent portions reprocessed at Scripps Institution of Oceanography [as shown in Figs. 3-5]. Dot-dash line is LDGO processed line extending toward Site 391 and shown in Fig. 2. The intersections of the track lines are shown at points $\mathrm{A}, \mathrm{B}$, and $\mathrm{C}$.)

Horizon $\mathrm{A}^{\mathrm{c}}$ (a reflection) has been shown to be related to either the shallowest occurrence of cherts or calcareous turbidites of the Eocene (Tucholke, 1979; Tucholke and Mountain, 1979). Along the margin the sedimentary unit associated with $\mathrm{A}^{\mathrm{c}}$ is missing and replaced by a major erosional unconformity, also marked by a prominent reflection, called Horizon $\mathrm{A}^{\mathrm{u}}$. The unconformity between either early Miocene and late Eocene and/or late Eocene and early Maestrichtian rocks at Site 534 is $\mathrm{A}^{\mathrm{u}}$; various cherty porcellanites were common near this same level. 
Horizon Beta $(\beta)$ is another prominent reflection correlated by Tucholke (1979) with the first appearance down-section of carbonate-rich sediments usually of the Barremian or Hauterivian. This transition, basically related to a shallowing of the $\mathrm{CCD}$, is believed to produce the prominent reflection observed in much of the North Atlantic.

Horizon $\mathrm{C}$ is a reflection that has only been routinely identified in more recent seismic surveys. It too is an extensive and continuous feature in the older part of the Basin (Dillon et al., 1976; Grow and Markl, 1977; Sheridan et al., 1978; Shipley et al., 1978). An age assignment has been made by Sheridan et al. (1978) and Jansa et al. (1979) on the basis of available data-essentially DSDP Sites 99, 100,105, and 391-that places Horizon C in the Tithonian related to the change down-section to more argillaceous (red) claystone observed at Site 391 (Benson et al., 1978).

Horizon $\mathrm{D}$ is a prominent reflection in the older part of the western Basin (Bryan et al., 1980; Grow and Markl, 1977; Shipley et al., 1978). As far as is known, this reflector does not crop out at the seafloor and was not previously sampled by drilling. Based on extrapolation of sedimentation rates below the drilled section at Site 391, Bryan et al. (1980) estimated the reflector at 155 m.y. near the base of the Callovian.

An assumption in the preceding review is that the correlation of the seismic data to the well hole was possible and correct. I will address in this report one method of improving our confidence in correlation of seismic reflection data to drill holes by using DSDP Site 534 to illustrate the problems, uncertainties, and reliability of well hole-seismic reflection correlations. I will also present an alternative to the Site 534 report correlation.

In its simplest form, correlation problems arise from trying to equate the seismic section, a time-domain record, to well hole stratigraphy, a depth-domain record. This procedure requires derivation of a velocity function to invert the time section to depth or the drill depth to time, which in practice is difficult. Because recovery is often incomplete, deep-sea drilling holes provide information on lithofacies but often not precise depths of stratigraphic breaks. For example, in the cored interval at Site 534 , recovery was only $56 \%$. Velocity of representative lithologies is routinely acquired in the shipboard laboratory but must in some way be corrected to in situ values. Then the corrected velocities must be weighted to the estimated lithology abundances before traveltime inversion of the data. Well logging has not been particularly successful or always possible in Glomar Challenger holes, preventing full use of these data.

The more common method used to find equivalence in drill hole depths and seismic reflection time sections is to correlate striking changes in lithology and occasionally drilling rate changes with major high-amplitude reflections using available regional geophysically derived velocities to estimate depths, when such information is available (i.e., Winterer et al., 1973; Hollister et al., 1972; Sheridan et al., 1978 and Site 534 report, this volume). Such methods of correlation are imprecise, but often no superior method is available. It is important to remember these problems when evaluating the published literature.

Most of these correlations directly equate lithology changes with seismic reflections. However, the sound energy as a complex wave train is reflected from positive and negative impedance boundaries (mismatches of the product of density and velocity), which may or may not correspond to obvious lithology changes. Indeed, the returned energy is the sum of the source wave train added to the various impedance boundaries added to other propagation effects, including internal multiples, spreading wave fronts and Fresnel zone averaging, which make it difficult to predict what causes reflections. Even with careful processing of seismic data to produce the sharpest image (or shortest wave train), we still must contend with the interference from adjacent impedance boundaries that may cancel or sum depending on the physical properties and their vertical spacing in the section.

Relying on correlations from other well holes, even nearby ones, requires some basic concept of what geologic information is contained in continuous reflections traced from some point to some other distant point. The physics of seismic reflections is well known; the vertical incident energy reflected from an interface is proportional to the change in the density-velocity product above and below an interface. The geologic significance or information portrayed in a seismic reflection section is not well understood. The geologic significance of reflections may be separated into two rather different problems. One is specifically related to a reflection at a single location, the other to the significance of laterally continuous reflections.

At a point a reflection may be caused by a change in lithology (facies) with depth that results in a change of velocity or density. The integration of the impedance function (caused by the velocity or density change) with the seismic wavelet is recorded on seismic sections. Thus reflections at a point are in response to vertical variations in lithofacies or sediment facies. Generally, laterally continuous reflection events do not follow facies boundaries. When we examine exposures of stratified rocks on land, the stratifications (bedding planes) are the laterally persistent physical surfaces that pass through facies boundaries and textural changes. Of course, the vertical variation in texture and composition between beds is usually greater than horizontal changes within an individual bed. Thus, as discussed by Vail et al. (1977), most laterally persistent reflections are probably related to bedding plane geometry and have some time significance. These same reflections may also have facies significance only if the facies changes are nearly instantaneous at the observation scale.

\section{SEISMIC REFLECTION DATA}

The seismic sections in the vicinity of Sites 391 and 534 that were used in the final selection of Site 534 are 24-fold multichannel data collected and processed by Lamont-Doherty Geological Observatory (LDGO) (Bryan et al., 1980). The source consisted of four 466 -in. ${ }^{3}$ air guns fired at about 2000 psi. The Bolt air guns were equipped with wave-shaping devices. 
Processing at LDGO consisted of Berg-type deconvolution (maximum entropy), time-varying filtering, and gaining, all after normal moveout and stacking (Fig. 2). Copies of three portions of the unstacked (though sorted) data where the lines form a triangle about Site 534 (Fig. 1) were obtained from LDGO. We reprocessed these three small portions of data, focusing on the deep reflections.

The processing sequence followed at Scripps Institution of Oceanography (SIO) was similar to that at LDGO. After correcting some problems resulting from sorting geometry, we ran semblance velocity analysis at five adjacent gathers nearest the drill Site on each of the three lines. The derived RMS (root mean square) velocity function was used to apply moveout to the data before stacking. The semblance velocities are considered unreliable for interval velocity calculations, because the data were sorted assuming perfect 24 -fold coverage that the shot and receiver spacing shows to be incorrect, and in any event, deep-water interval velocities are difficult to extract using the standard length array. The data were then deconvolved with a spiking operator designed from the data trace between 6.5 and $8.0 \mathrm{~s}$. Finally, the data were bandpass filtered 6 to $45 \mathrm{~Hz}$ (Figs. 3, 4 and 5). A number of tests of velocity functions, constant velocity gathers, filter and deconvolution parameters (particu- larly shorter design windows) applied before and after stack did not yield significantly better results between 7.2 and $8.0 \mathrm{~s}$, the zone of primary interest.

The LDGO processing is clearly superior in the shal. lower section (compare Figs. 2 and 3). However, the deconvolution operator was not particularly successful at greater depths where the velocity was much higher and thus the wave-train periodicity was greatly lengthened. The spiking deconvolution used at SIO did not significantly reduce the seafloor reflection doublet to a single spike but it did modify the deep reflections below $7.4 \mathrm{~s}$. Comparison of filtered (Fig. 6) versus deconvolved and filtered data (Fig. 5) shows that the primary reflections were not altered but that a possible bubble pulse has been reduced. The particular deconvolution parameters used in these plots were selected because of their ability to sharpen the deeper reflections. A different set of parameters (or time-varying deconvolution) will improve the shallow portion of the section as shown by the LDGO section in Figure 5, but this was not the objective of this project.

An objection can always be raised that the deconvolution operator is being designed on reflections having geologic significance. This was evaluated in two ways. First, a before and after deconvolution comparison is illustrated in Figures 6 and 5, respectively. Note that just

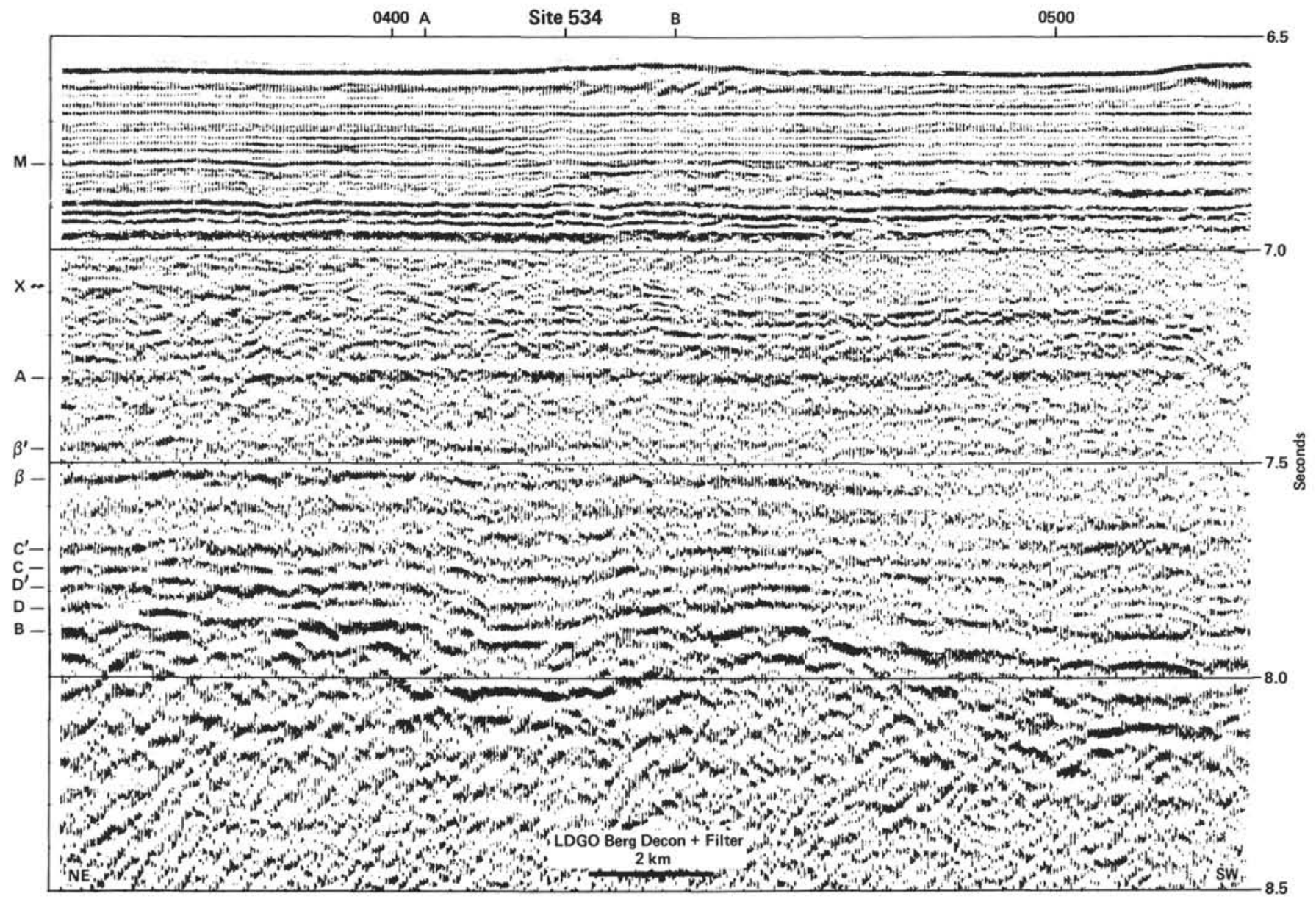

Figure 2. LDGO 24-channel seismic reflection section through Site 534 (see Fig. 1 for location). 


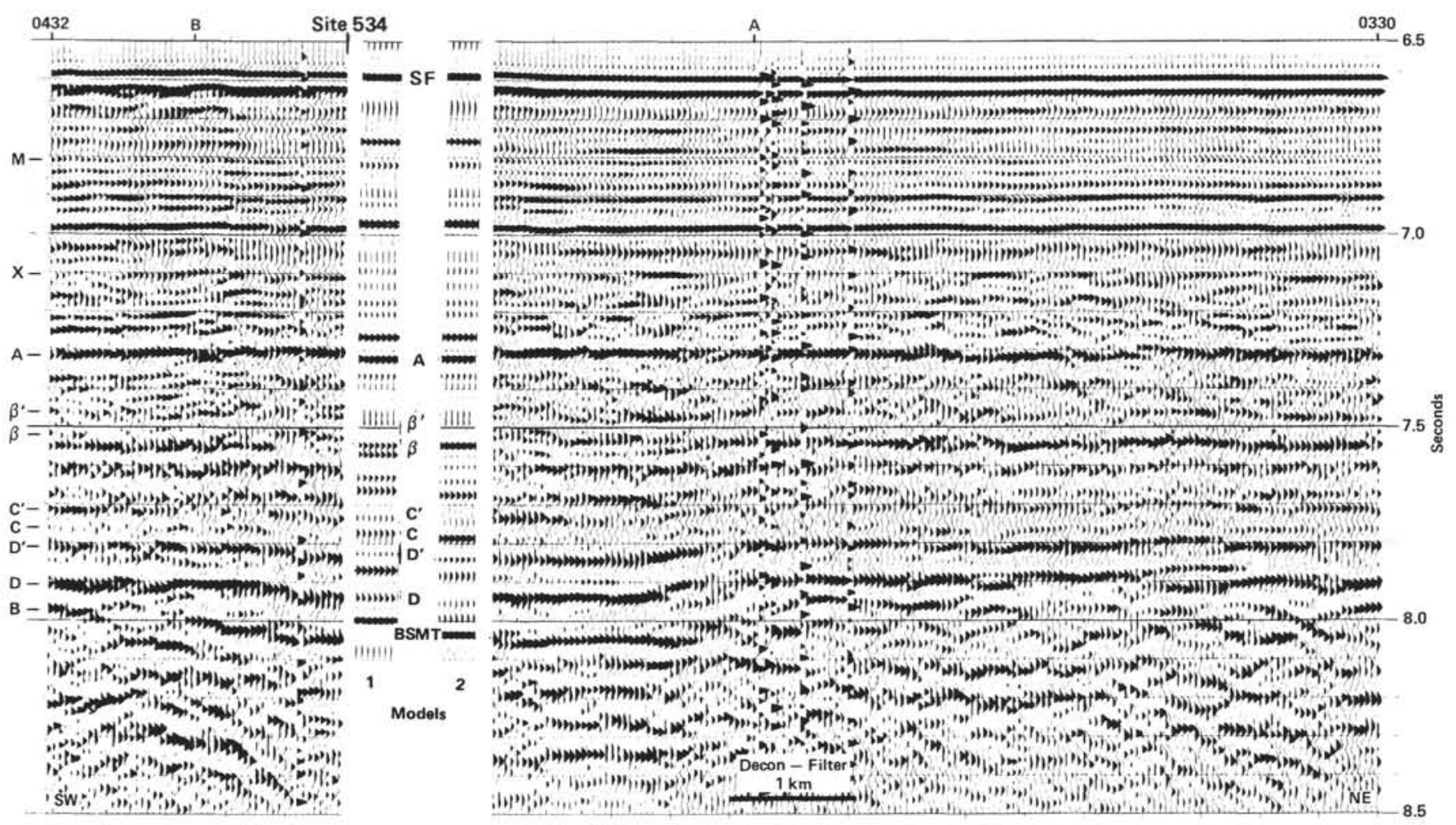

Figure 3. Portion of section in Fig. 2, reprocessed to enhance the resolution and clarity of the deeper reflections. (Insert is Models 1 and 2 from Fig. 11. $\mathrm{SF}=$ seafloor.)

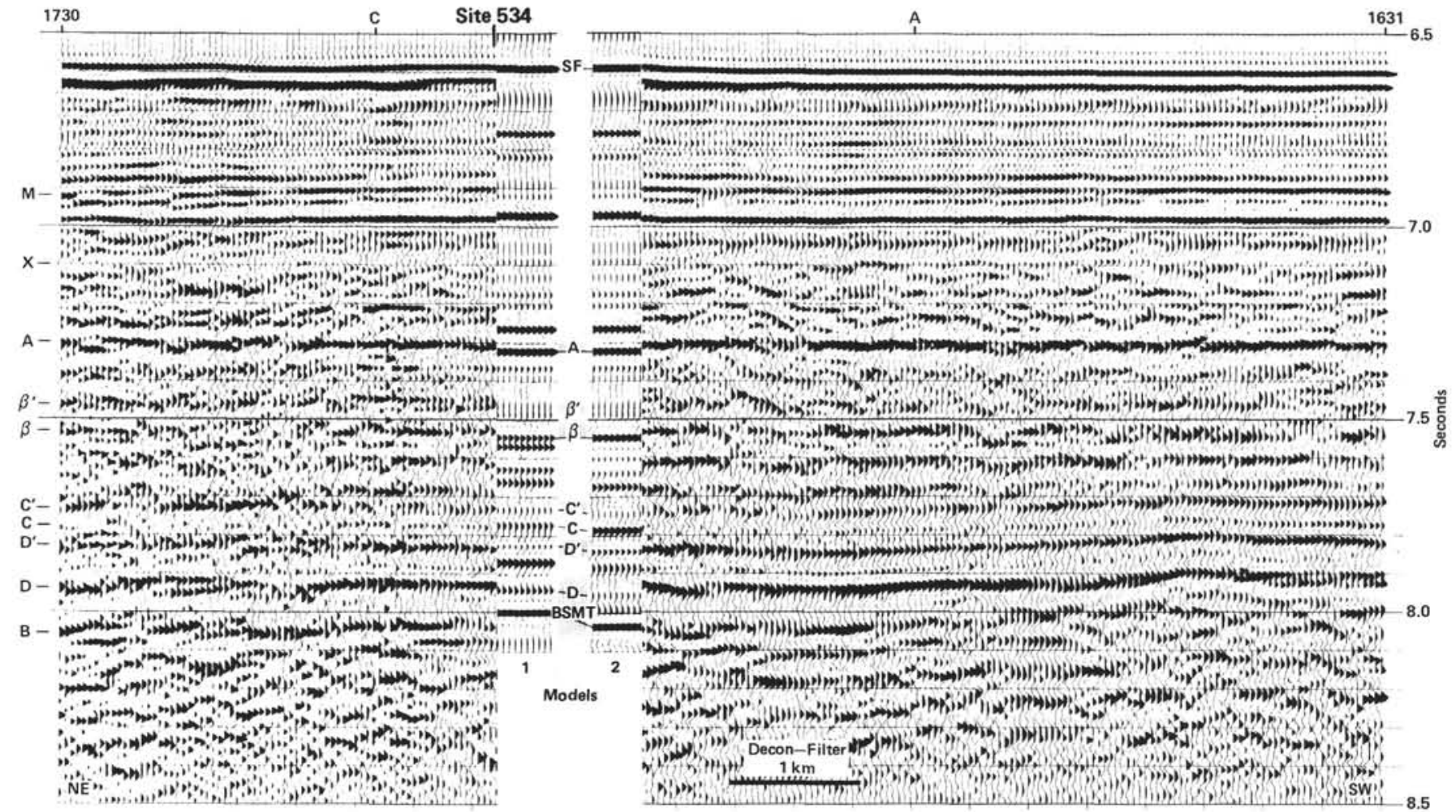

Figure 4. Seismic section reprocessed to enhance resolution and clarity of the deeper reflections. 


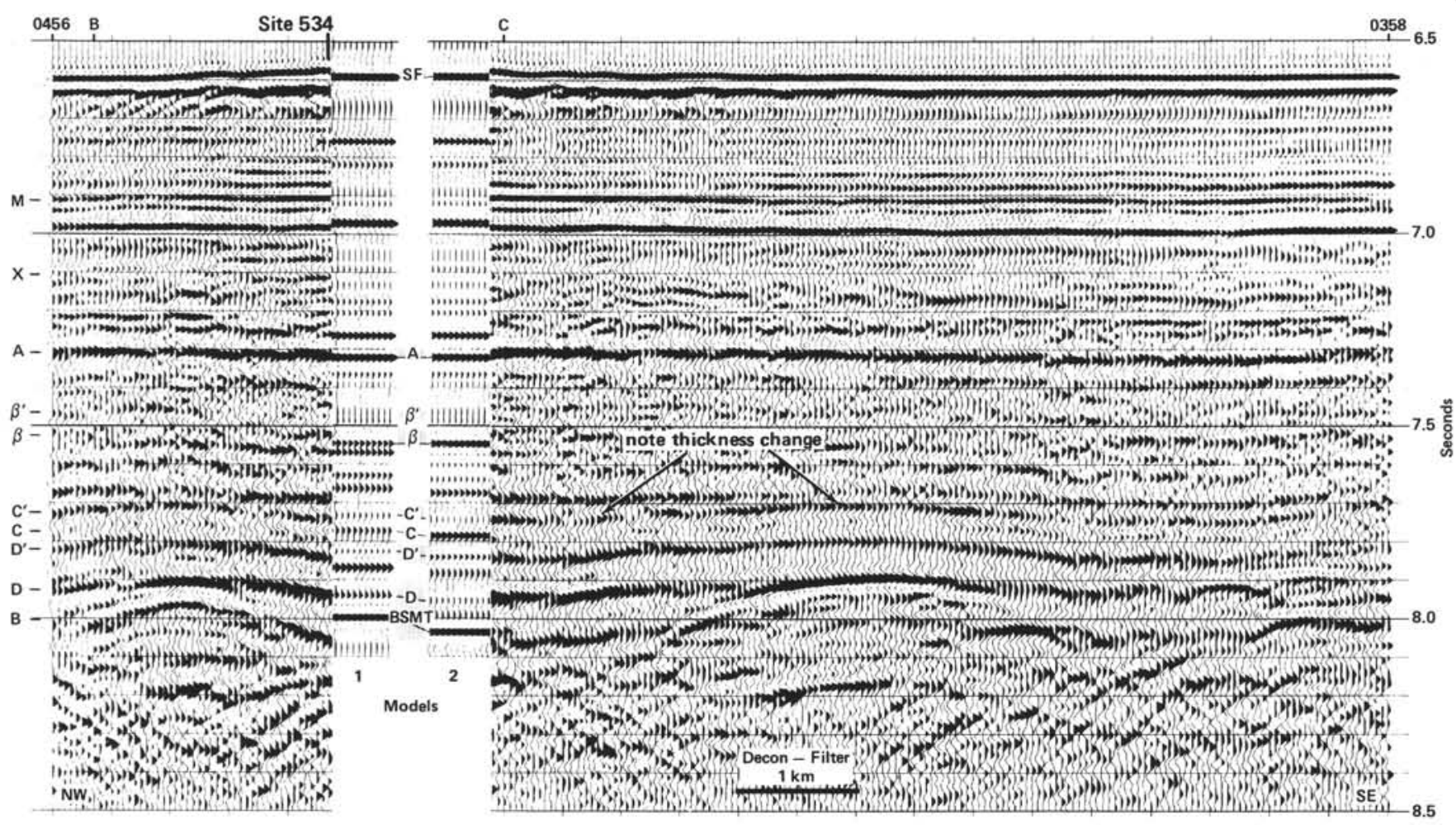

Figure 5. Seismic section reprocessed to enhance resolution and clarity of the deeper reflections. (Note the thickness change and relief labeled near $7.7 \mathrm{~s}$. This may denote a change in depositional patterns [from sheet drape below to basin-fill above] and possible minor unconformity.)

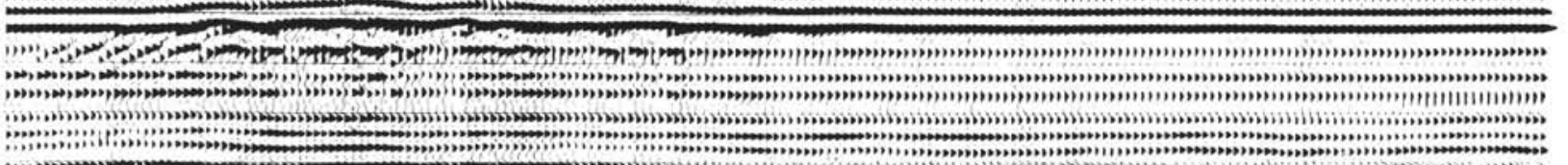

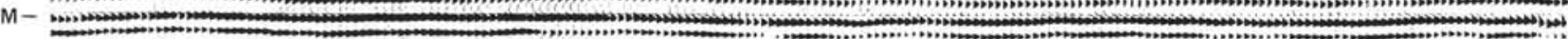

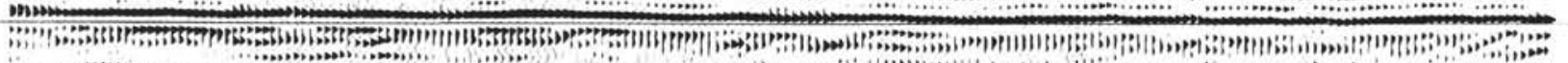

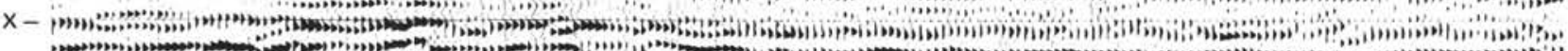

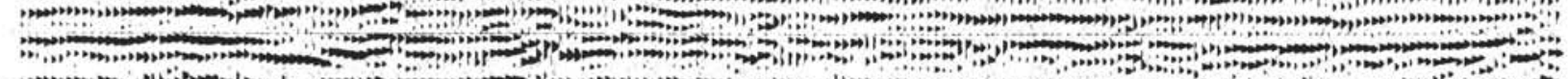

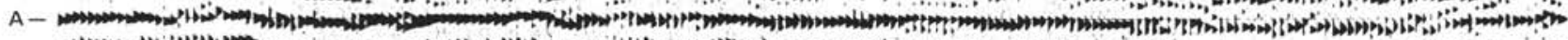

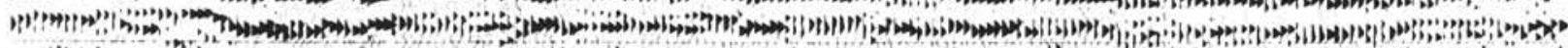

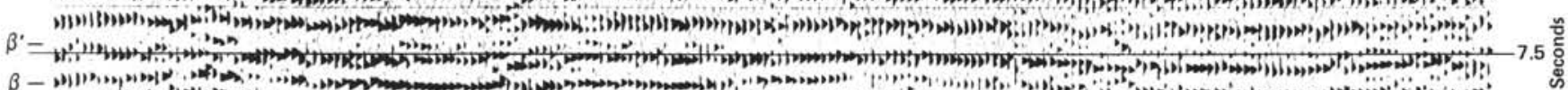

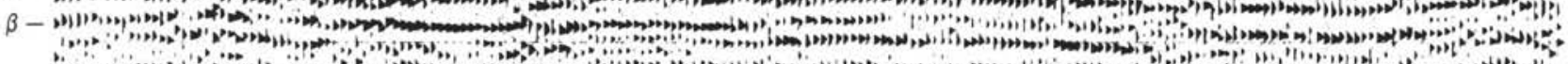

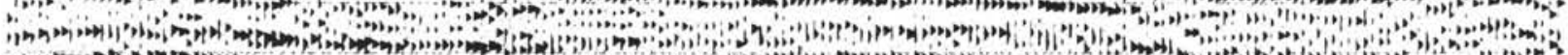

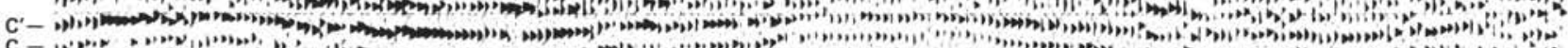

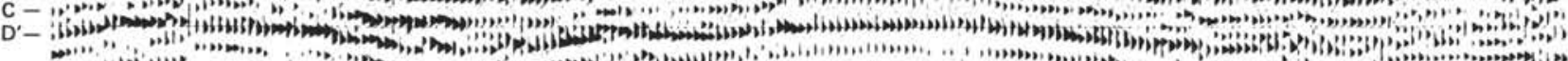
_

D - = ; ? ? Pon (n) InW,

Figure 6. Same seismic section as in Figure 5 but without deconvolution to evaluate the quality of the processing procedure. 
above $C^{\prime}$ in Figure 6 a pair of reflections shows a thinning geometry. This same subtle feature is observed in the deconvolved version (Fig. 5), suggesting that the deconvolution is not destroying the geometrical relationships. A second attempt to evaluate the effect of deconvolution was to deconvolve the synthetic seismogram of Model 3 (discussed later), which has 176 layers. The deconvolution did not significantly alter the input again, suggesting that there is no obvious periodicity in the geology.

The navigation for the seismic array was LORAN $\mathrm{C}$-an accurate system that, when available, is superior to satellite systems for underway ships. Fixes can be obtained at any time and the ship's velocity is not a variaable in solving for the position, as in the present satellite systems. The location of the Site is based on the mean of a number of satellite fixes while the Glomar Challenger was positioned on site. Location of both the hole and the seismic data are quite good. However, the frames of reference are not readily comparable. Thus the position of the Site relative to the seismic data is not exactly known. To evaluate the significance of this problem we have noted the variation in traveltimes to identified reflections along the seismic sections that form a triangle around the Site (tabulated in Table 1). The triangle has no error significance but does form a convenient limit for investigating variations in the geology near the Site.

The portions of the seismic lines within the triangle are shown in Figure 7. These data illustrate that the traveltimes are nearly constant down to Horizon $C^{\prime}$. Only below Horizon $\mathrm{C}$, that is $\mathrm{D}, \mathrm{D}^{\prime}$, and basement, is there significant relief and variation in traveltime, and thus relative hole location errors become more important. Even so it seems most important only for basement, which varies in total round-trip travel time $0.15 \mathrm{~s}$, whereas $\mathrm{D}$ varies only $0.04 \mathrm{~s}$.

Table 1. Two-way traveltime to identified seismic reflections in seconds on three lines surrounding Site 534 .

\begin{tabular}{ccc}
\hline Reflection & Reflection time ${ }^{\mathrm{a}}$ & $\begin{array}{c}\text { Closest approach } \\
\text { meanb }\end{array}$ \\
\hline Seafloor & $6.57-6.60$ & 6.58 \\
A & $7.30-7.32$ & 7.31 \\
$\beta^{\prime}$ & $7.46-7.48$ & 7.47 \\
$\beta$ & $7.51-7.54$ & 7.52 \\
C $^{\prime}$ & $7.71-7.74$ & 7.74 \\
C & $7.76-7.79$ & 7.79 \\
D $^{\prime}$ & $7.81-7.85$ & 7.84 \\
D & $7.91-7.95$ & 7.94 \\
Basement & $7.91-8.06$ & $8.05^{\mathrm{c}}$ \\
\hline
\end{tabular}

a Maximum range of reflection times. Note that these are extreme values and that the $\Delta$ range between any two reflections is always much less (i.e., most sediments are draping basement).

b The mean of the times at the closest approach point on each of the three lines (see Fig. 7).

c Calculated basement time in Model 1 is $7.99 \mathrm{~s}$ and in Model 2 is $8.03 \mathrm{~s}$, both less than the mean. This is one measure of the integrated errors, in traveltimes and location.
The correlations to identified seismic reflections on Figures 2 through 7 are from Bryan et al. (1980), modified slightly by Sheridan et al. (this volume).

\section{PHYSICAL PROPERTIES}

A variety of physical property measurements was made on the materials recovered at Site 534 and from downhole logging of density (Figs. 8 and 9 and Table 2). Density and caliper logs were collected between 490 and $730 \mathrm{~m}, 925$ and $1375 \mathrm{~m}$, and 1410 and $1480 \mathrm{~m}$. Velocity data with malfunctioning caliper were collected between 490 and $725 \mathrm{~m}$. The laboratory measurements suffer from various uncertainties (see the Explanatory Notes chapter). The most significant problems are with methods to extrapolate the effect of in-place conditions on density and velocity and of weighting the appropriate values to represent the real distribution at the drill site, because the drilling procedure creates a bias in recovery.

A velocity and density function appropriate to in situ conditions was calculated as follows. Porosity rebound was taken from Hamilton (1976) and entered on a cross plot of laboratory porosity and vertical velocity to establish the estimate of in situ velocity. The in situ velocity was then entered on a cross plot of the velocity and density to establish an in situ density. This procedure to calculate in situ vertical velocities from the porosity rebound was modified only where the density log indicated significant departures from the results of calculated in situ density.

The lithologic units defined by the sedimentologists (Site 534 report) were used to subdivide the section into intervals. Within each interval means of measured velocity, density, and porosity of each major lithology were calculated. Lithology Units 3, 5a, and 6a were further subdivided because of detected changes in physical properties or abundances not considered relevant to the sedimentology. Using these units results in a fairly unbiased subdivision of the sedimentary section.

The first-order porosity correction to the laboratory data at Site 534 is based on empirical consolidation tests on terrigenous and carbonate deep-sea sediments by Hamilton (1976). Specifically, the porosity rebound from pressure unloading was based on the sediment lithology according to Hamilton's data. Below $950 \mathrm{~m}$ the density log in the terrigenous mudstones was interpreted to suggest no systematic rebound (though data are lacking between about 700 and $925 \mathrm{~m}$ ), and a rebound correction combining this fact with Hamilton's data to $600 \mathrm{~m}$ was used (Fig. 10). Note that these densities result in mudstone in situ vertical velocities of 1.8 to $1.9 \mathrm{~km} / \mathrm{s}$ in the intervals between 764 and $950 \mathrm{~m}$. We assume that the rebound function in Figure 10 is reasonable, but the absence of logging data in the interval leaves doubt about this trend. The log data also suggest that rebound in the carbonate chalks and oozes closely follows Hamilton's curve and is limited to depths $<700 \mathrm{~m}$. No significant amount of chalk was encountered between 714 and $976 \mathrm{~m}$ and no extrapolation of Hamilton's data was necessary. Below $976 \mathrm{~m}$ the "chalks" were lithified enough that rebound was probably insignificant, which 


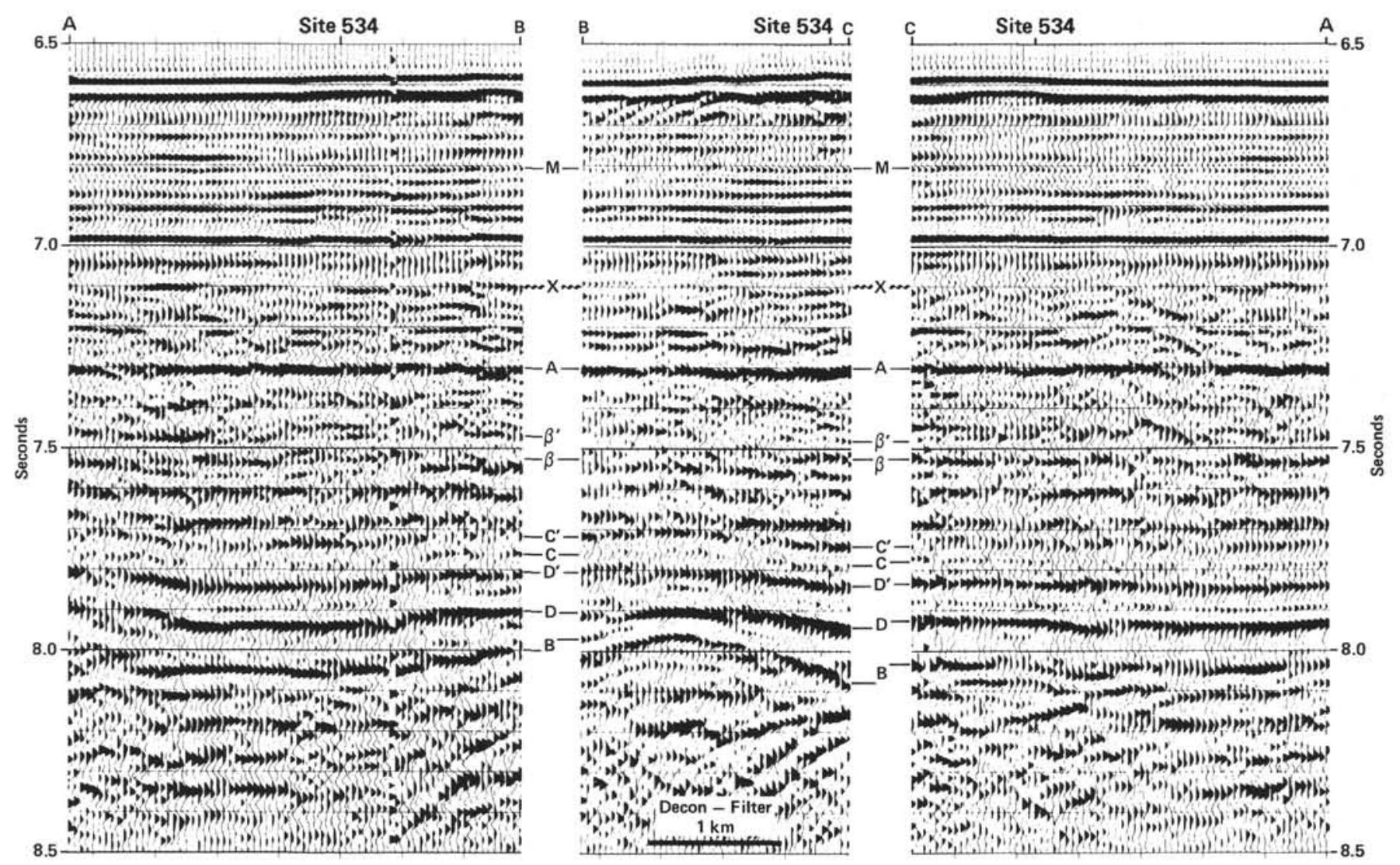

Figure 7. Portions of seismic lines that form a triangle around Site 534. (These sections allow us to estimate maximum likely variation in reflection times resulting from uncertainties in drill hole location relative to the seismic reflection lines [see Table 1].)

is supported by the density log (Fig. 9). No systematic rebound was detected or applied to the lithified limestones.

A number of other conditions that have not been discussed also have an effect on the physical properties, the most important being temperature and pressure, which increase the velocity of sound in water in the pore spaces (see Boyce, 1976). Laboratory measurements were made at $1 \mathrm{~atm}$ and at about $20^{\circ} \mathrm{C}$ while in situ pressures varied from 500 to $600 \mathrm{~atm}$ and from $20^{\circ} \mathrm{C}$ at $600 \mathrm{~m}$ to $45^{\circ} \mathrm{C}$ at $1600 \mathrm{~m}$. At $600 \mathrm{~m}$ the combined effect is about a $6 \%$ increase in sound velocity in water and at $1600 \mathrm{~m}$ an $11 \%$ increase (Press, 1966). The exact relationship between sound velocity in the water of the pore spaces and velocity in the saturated sample at high pressures is not well documented (Boyce, 1976). However, the inferred higher velocities in the pore waters imply that the muds may have velocities perhaps up to 3 or $4 \%$ higher than shown in Table 2 and slightly greater at the base of the hole. The lithified chalks and limestones probably have a lesser increase in velocity.

When the corrected density model is overlain by the log density data (Fig. 9), departures from predicted values are noted in Subunits $2 a, 2 b, 2 c, 5 c$, and $5 d$. In Subunits $2 \mathrm{a}$ through $\mathrm{c}$ the differences did not significantly alter velocities, because the slope of the density versus velocity function at these low densities is gentle (Fig. 8). I see no obvious reason for the departure from Hamilton's data. In Subunits 5c and 5d, where there were par- ticularly good hole conditions and in Subunit $5 \mathrm{~d}$ with a nearly uniform limestone lithology, the calculated densities appear too low, though in adjacent units the laboratory and log data are similar. These high densities for the limestone suggest significantly higher velocities, as shown in Table 2 . The section contained more homogeneous nannofossil limestones than some other units, so I remain puzzled as to the cause of the shift in densities.

Corrections similar to those for Units 2 and 5 were not applied to other units without good log data, because the density corrections are not systematic. Also, the assumption is not proven that the well logs provide better estimates of in situ densities than do the corrected laboratory values. Drilling may have caused fracturing and deformation of the soft mudstones, and surface salt water could have replaced the formation fluid. Perhaps most important, the density tool samples a rather larger part of the formation, averaging both horizontal and vertical variations in physical properties (on the order of $30 \mathrm{~cm}$ at minimum hole diameter [Boyce, 1980]). Log resolution is further reduced by vertical motion of the ship relative to the hole.

The vertical velocity and density for each unit was weighted to the relative abundances of the lithologies in the recovered section to produce a mean velocity and density for each unit (Table 2, Model 1). These relative abundances may be biased, however, by the preferential recovery of more massive moderately firm layers, whereas the drilling process may tend to wash away muds, 

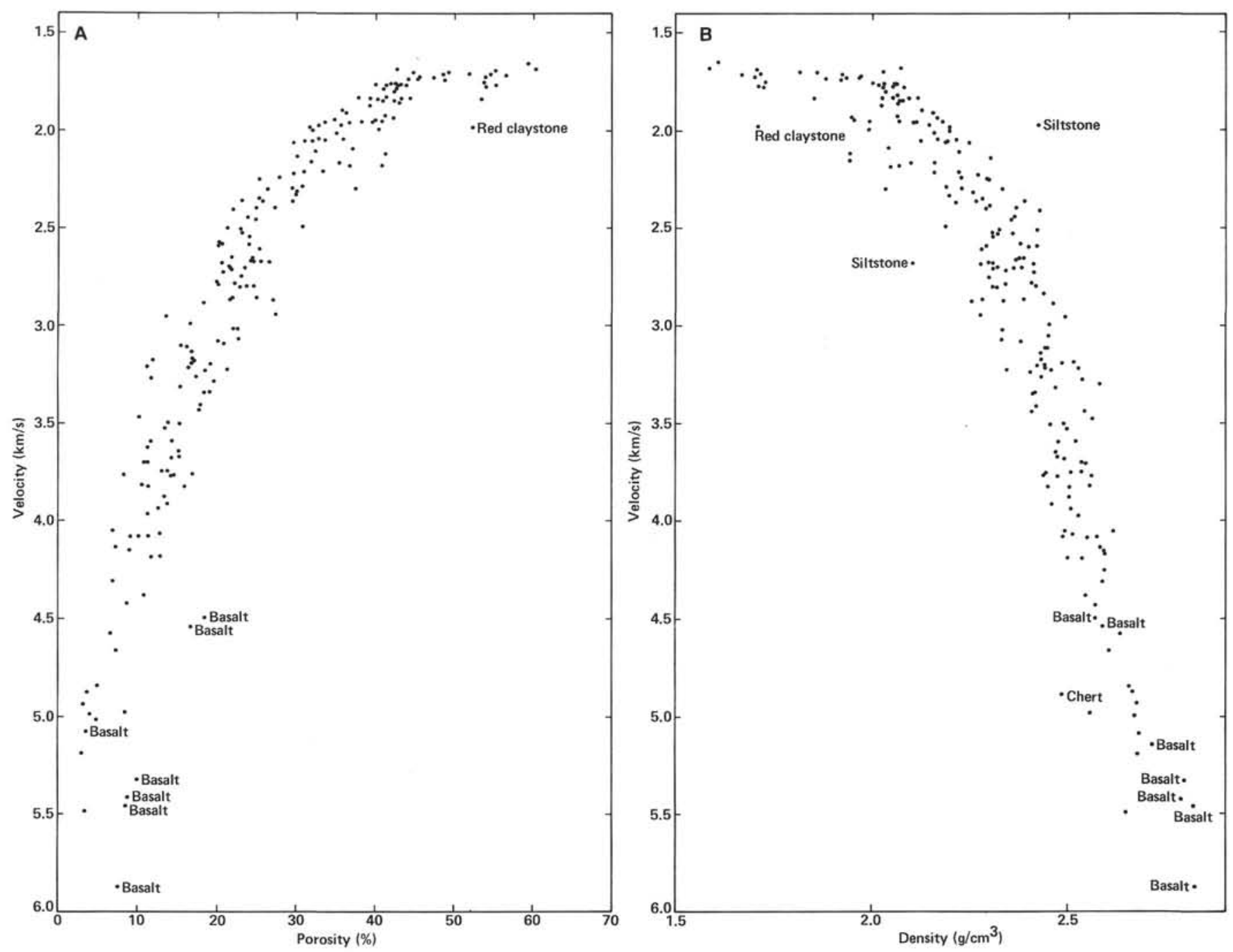

Figure 8. Cross plots of the vertical velocity versus porosity and density measured in the laboratory on the same samples at Site 534 (see Site 534 report). (These plots were used to determine trends for estimating in situ density and velocity.)

very hard thin layers, or interbeds of muds. In an attempt to evaluate the significance of this problem for the likely case in which much of the cored but unrecovered section may consist of mud, mean unit values were recalculated using mud (mudstone) velocity and density for all the unrecovered sections. This then gives one likely end member in the total traveltime through the section (Table 2, Model 2).

Another problem at Site 534 is that we only cored between $545 \mathrm{~m}$ and total depth. Casing was set to $536 \mathrm{~m}$ and the sediments were not cored or logged between 3 and $545 \mathrm{~m}$. I have used a combination of data from nearby Site 391 and published velocity information to constrain the physical properties models in this interval. The velocities and thickness of the upper section were adjusted to position reflector $\mathrm{X}$ at $7.1 \mathrm{~s}$ subsurface and proceeded below $500 \mathrm{~m}$ with velocities and densities derived directly from the data at Site 534 , as discussed earlier. The Eocene-Maestrichtian unconformity at $723.5 \mathrm{~m}$ is correlated with Horizon A. This correlation and the depth at which basalt was first encountered at $1639 \mathrm{~m}$ are two end points in the seismic modeling.

\section{SEISMIC MODELS}

Synthetic seismograms were produced from the physical property data collected at this Site. Three models were generated, two mainly to place some limits on the traveltimes involved and a third to evaluate in a crude manner reflection characteristics (Fig. 11).

All models used wave-theory solutions based on a wavelet defined in the frequency domain as 10 to $35 \mathrm{~Hz}$ with a nearly zero-phase character. This particular wavelet was picked on the basis of the frequency spectra of the stacked field data. Rather arbitrarily we assumed a source depth of $10 \mathrm{~m}$ and a receiver depth of $20 \mathrm{~m}$ for calculation of the surface ghost. The attenuation effects were ignored and the model output was filtered and amplitude adjusted to approximate the amplitude of the processed field data. For simplicity, the velocity and density functions were modeled with horizontal layers.

\section{Model 1}

The first model used as input to the velocity-density function is shown in Table 2 . This model assumes that 
PHYSICAL PROPERTIES, SYNTHETIC SEISMOGRAMS AND SEISMIC REFLECTIONS

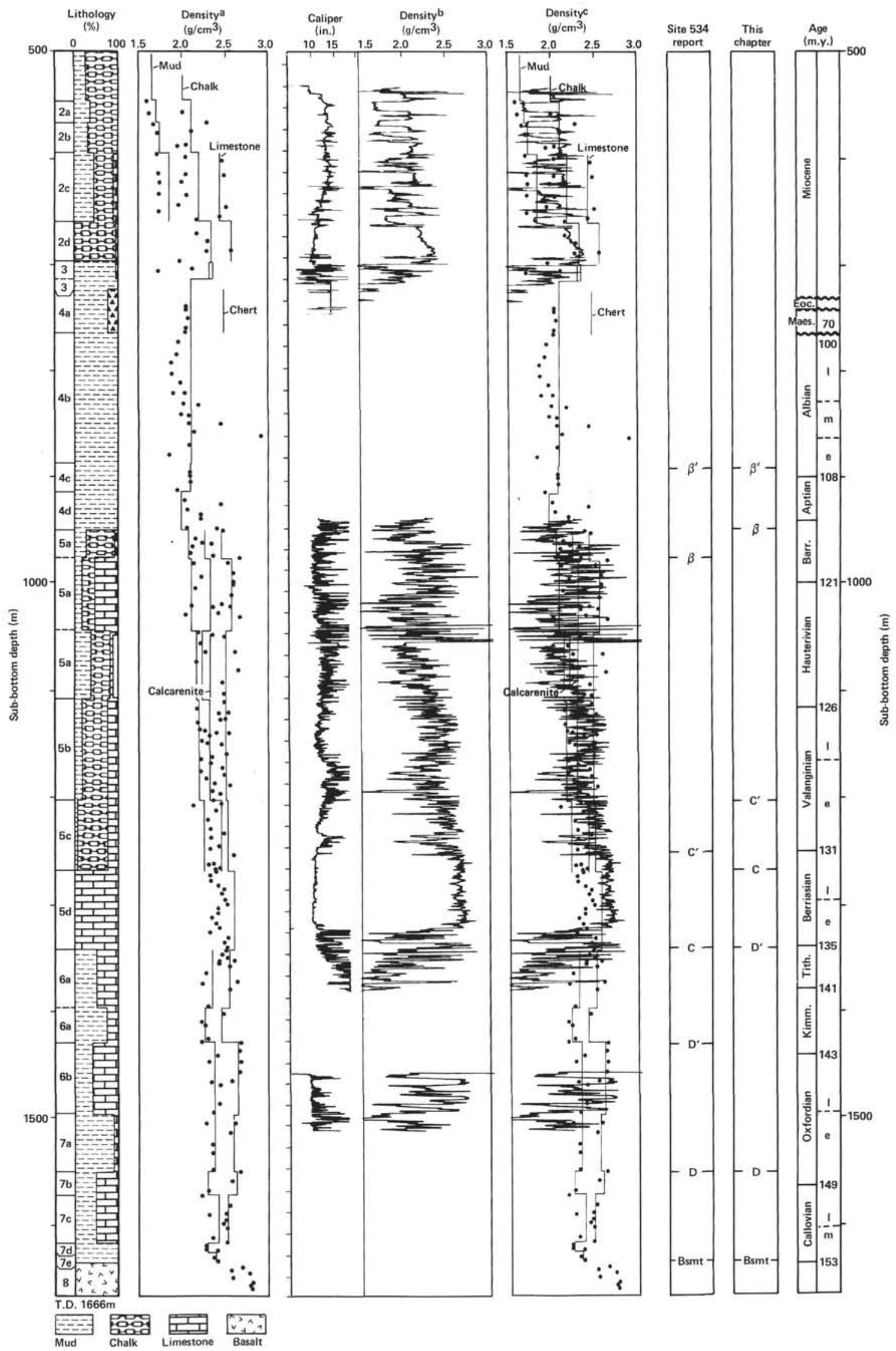

Figure 9. Profile showing major lithologies and densities versus depth at Site 534. (Density ${ }^{\mathrm{a}}$ column shows laboratory data points and calculated in situ unit densities for each major lithology [up to four per unit, solid lines]. Density ${ }^{b}$ column is density measured in the hole during logging. Hole diameter is shown in column labeled caliper. Density ${ }^{\mathcal{C}}$ column shows logging densities overlain with corrected in situ densities for each major lithology. Note that additional corrections were necessary in Units $2[a, b, c]$ and $5[c, d]$. 


\section{T. H. SHIPLEY}

Table 2. Summary of physical property data, Site 534.

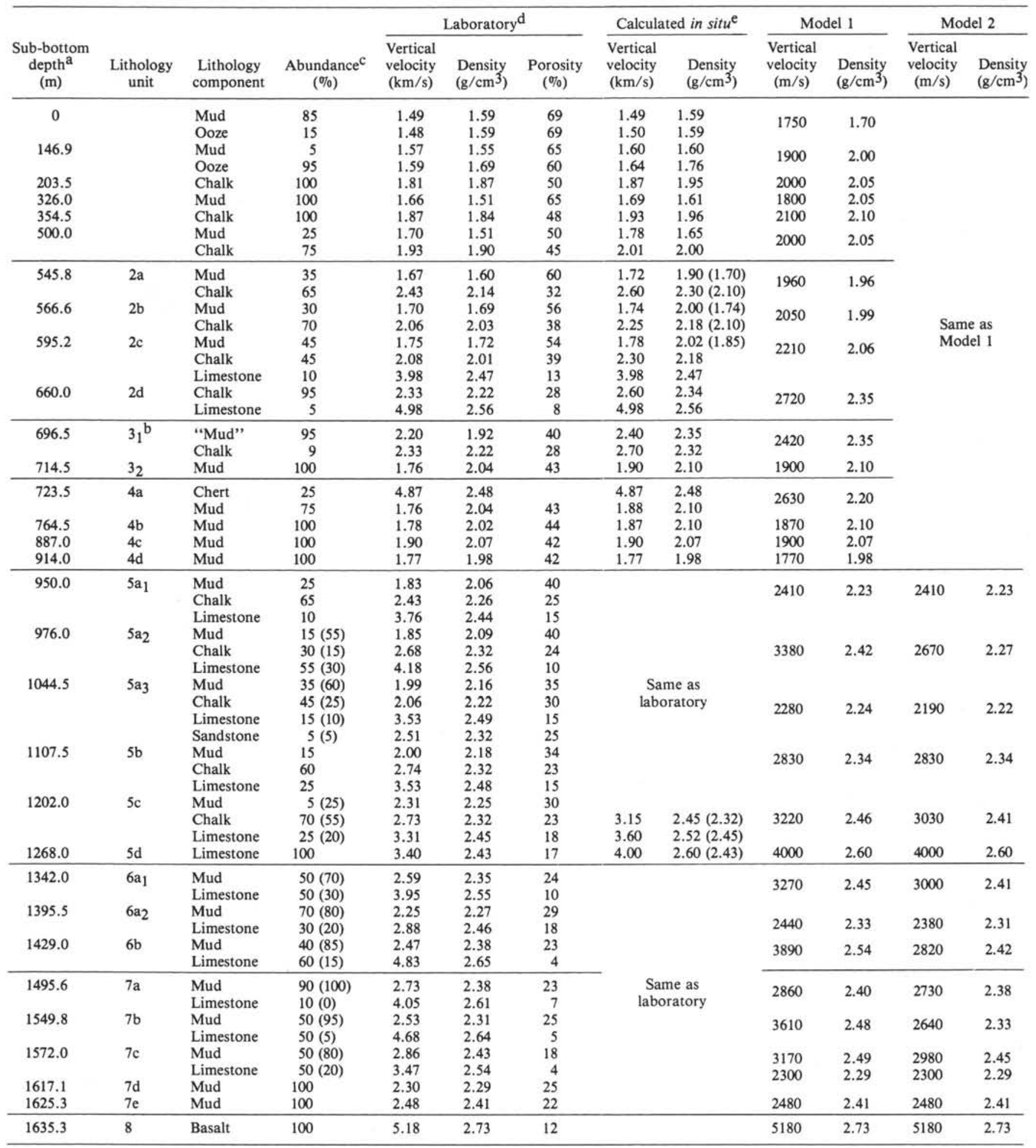

${ }^{a}$ From 0 to $500 \mathrm{~m}$, values are from Site 391; from 500 to $545.8 \mathrm{~m}$, values are a combination of data from both sites.

b Subscript shows further subdivision of the lithologic subunit to indicate changes in physical properties or abundances not considered relevant to the sedimentology.

c Component estimates in brackets assume all unrecovered section is mud-mudstone. These were used in Model 2.

${ }^{d}$ Laboratory data from gravimetric wet-bulk density and vertical velocities measured at Site 534, supplemented in a few places with data extrapolated from adjacent units.

e In situ corrections based on porosity rebound of Hamilton (1976) with qualification that the density log was interpreted to indicate no systematic rebound for terrigenous sediments below $940 \mathrm{~m}$ and below $700 \mathrm{~m}$ for chalks. Where log densities varied significantly from calculated values (shown in parentheses), these were used to determine in situ velocity and used in the models. There are no corrections for hydrostatic pressure or temperature. 


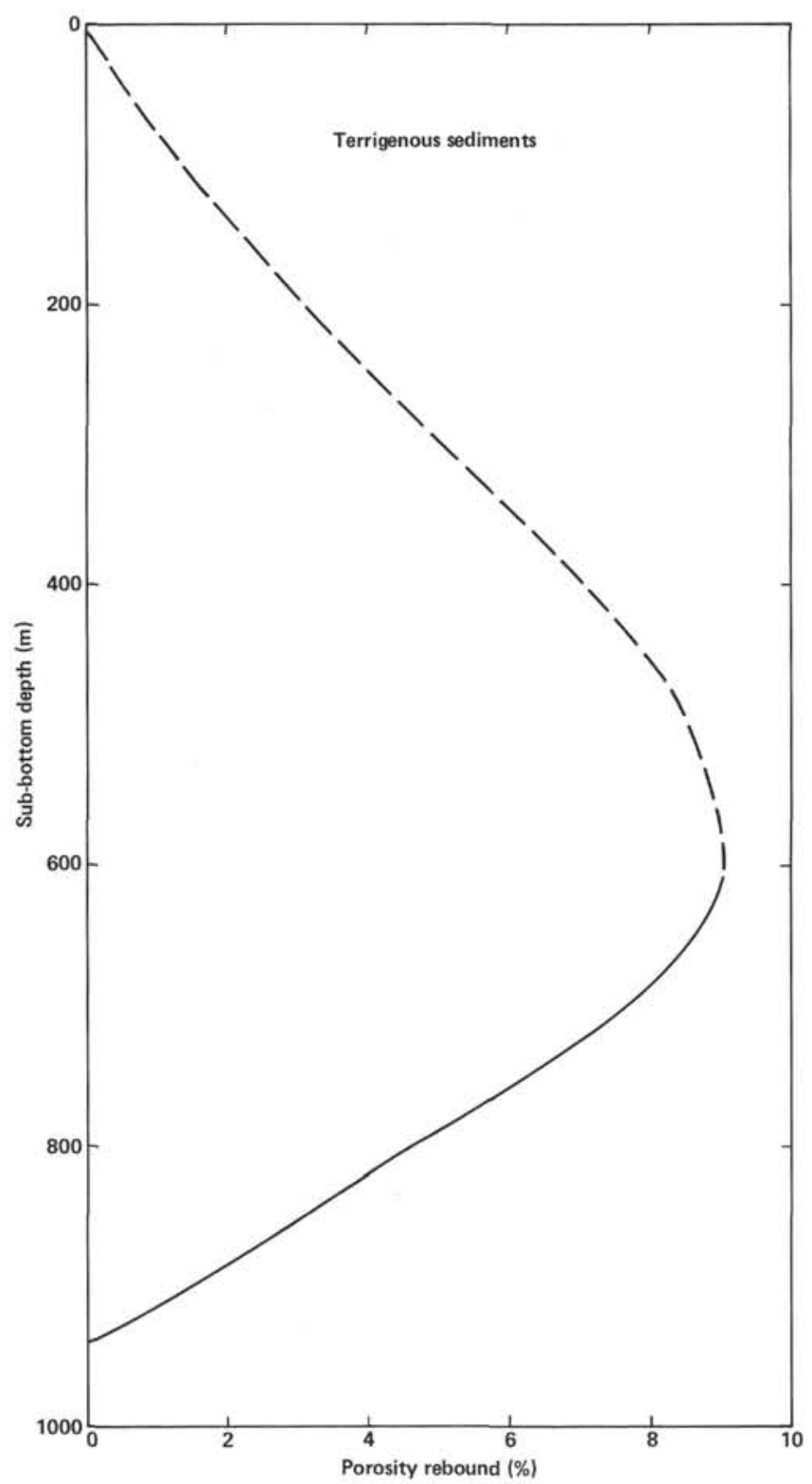

Figure 10. Function used to correct for unloading porosity rebound. (The dashed portion is after Hamilton [1976]; the solid portion is based on interpretation of the logging data.)

the $44 \%$ unrecovered section is of the same lithologic proportions as the recovered section. The physical properties and depth from seafloor to reflection $\mathrm{X}$ are not well constrained and were adjusted, as shown in Table 2, to make the traveltime agree with the correlation in the drill hole. Below $7.1 \mathrm{~s}$ the model parameters were not modified.

\section{Model 2}

A second model was constructed to constrain the lowest velocity, maximum traveltime that might be expected from preferential poor recovery of muds and mudstones. In this model it was assumed that any unrecovered section below $723.5 \mathrm{~m}$ was mud or mudstone, and the mud percentage was increased to reflect the unrecovered interval within a unit. This results in a situa- tion useful in constraining maximum possible traveltimes.

\section{Model 3}

A third model was created that input each velocitydensity laboratory data point starting in Subunit $4 \mathrm{c}$ $(887 \mathrm{~m})$. Shallower laboratory data were not used, because each point would have had to be corrected to in situ values, while below Subunit $4 \mathrm{~b}$ only Subunits $5 \mathrm{c}$ and $5 \mathrm{~d}$ have laboratory velocities that differ significantly from in situ conditions (we did not correct $5 \mathrm{c}$ and $5 \mathrm{~d}$ in Model 3). The purpose of this model was to evaluate not traveltimes but wavelet shapes and the interaction of closely spaced beds.

At sea, I tried to sample each lithology in each core, or if only a single lithology, two samples of that lithology. This procedure results in highly biased sampling, because in most cores one lithology was usually dominant, but the minor lithology was also sampled. This sampling interval, about 2 per $9 \mathrm{~m}$, is well below the seismic wavelet length of between 50 and $100 \mathrm{~m}$. Thus the sequence may give a fair representation of key reflection events, though the traveltimes are not as well constrained as in Models 1 and 2.

Additional models with other sets of data based on drilling rates or abundance estimates from the density log could have been attempted, as well as other functions to determine in situ velocities, but all require significantly more assumptions. For example, using drilling rate changes requires knowledge of bit condition, weight on bit, pumping rates, mechanical characteristics of the sediment and their response to a particular bit type; and then correlation of sediment mechanical properties to seismically relatable physical properties. Only the two aforementioned models with clearly defined assumptions have been used to constrain possible traveltime correlations to the seismic section.

\section{RESULTS}

The preferred correlation based on the models is shown in Figure 9. Not surprisingly, because of differing techniques, these correlations differ in some important respects from the correlations shown in the Site 534 report.

Horizon $\beta^{\prime}$ is the deeper of a weak pair of reflections in the field data near the Site. In the models the doublet is created by the spacing and sum of the slight positive impedance contrast between Subunits $4 \mathrm{~b}$ and $4 \mathrm{c}$ and the slight negative impedance contrast between $4 \mathrm{c}$ and $4 \mathrm{~d}$. The deeper of the two reflections, identified as $\beta^{\prime}$, is apparently produced from this bed spacing and the shape of the seismic wavelet and is thus not a very convincing correlation, particularly because this character is not evident in Model 3. However, as might be expected in such a case, the doublet is not laterally persistent (Fig. 2). $\beta^{\prime}$ is correlated with the top of Subunit $4 \mathrm{c}, 887 \mathrm{~m}$ sub-bottom (108 m.y., basal Albian).

The reflection identified as $\beta$ in Figure 7 is the shallower of a second doublet in the field data. This doublet is present but not clearly observable in the LDGO processed section and occurs most convincingly in Figure 7 


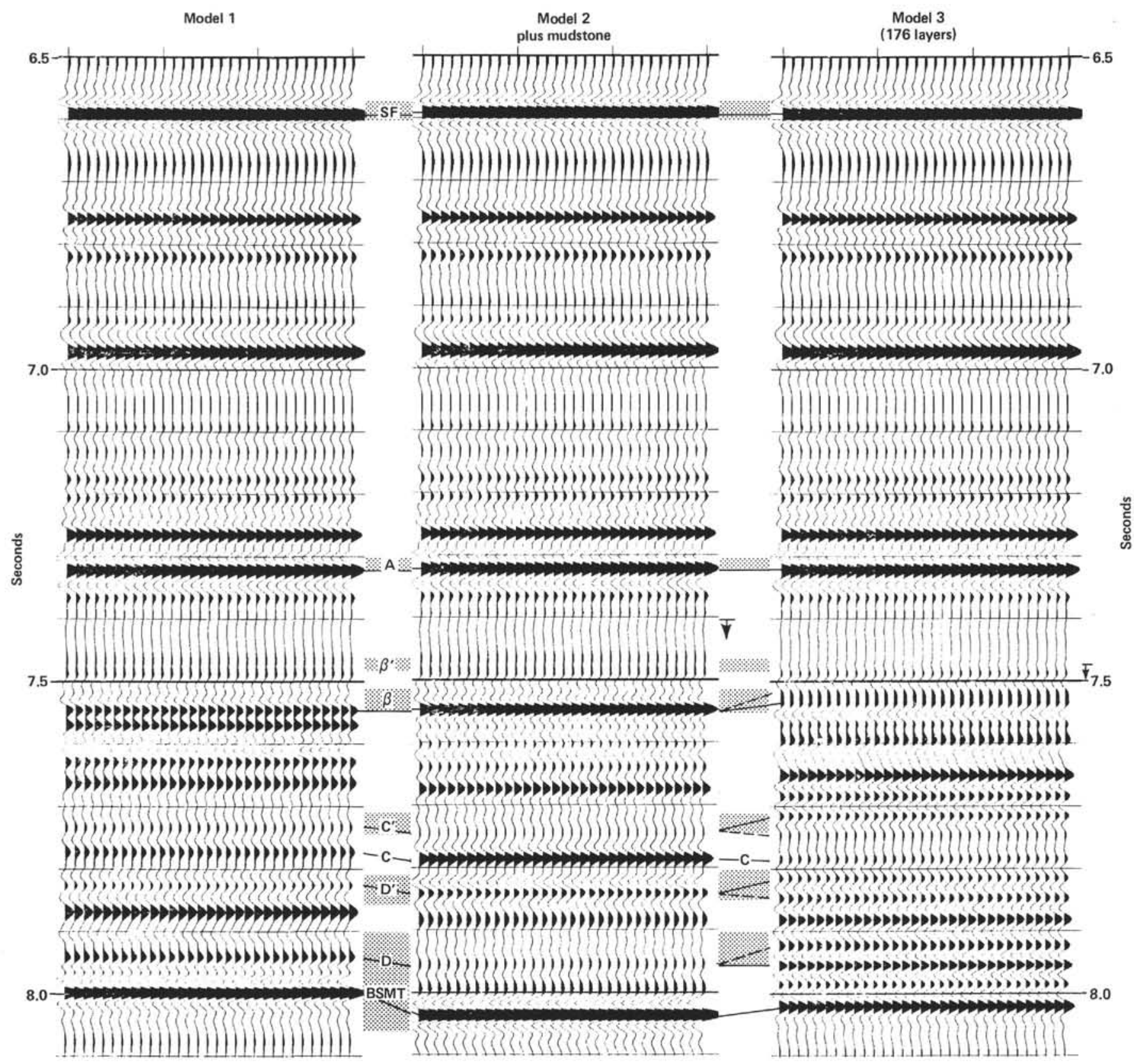

Figure 11. Output of three basic models described in text. (Below arrows to the right of Models 2 and 3 are portions of models that were varied from Model 1. Shaded bars at indicated reflection horizons represent range of observed traveltime to the horizons near Site 534.)

near the Site. In both models the reflection corresponding to the upper part of the doublet in the field data is at $950 \mathrm{~m}$. The impedance contrast between $4 \mathrm{~d}$ and $5 \mathrm{a}$ is stronger than the one between $5 \mathrm{a}_{1}$ and $5 \mathrm{a}_{2}(0.21$ versus 0.06 in Model 2) and is associated with the rapid increase in chalks. Thus Beta is correlated to the top of the chalks at $950 \mathrm{~m}$, in the upper Barremian.

Three reflections generally occur between $\beta$ and $C^{\prime}$ on the field records. These may correspond to the positive contrast between Subunits $5 \mathrm{a}_{1}$ and $5 \mathrm{a}_{2}(976 \mathrm{~m})$ at the first occurrence of limestones, a strong negative contrast between $5 \mathrm{a}_{2}$ and $5 \mathrm{a}_{3}(1044 \mathrm{~m})$, and moderate positive contrast between $5 \mathrm{a}_{3}$ and $5 \mathrm{~b}(1107 \mathrm{~m})$. For this simplistic correlation, the thickness of the units must be such as to reinforce the reflections. This may be evident from the variation in amplitudes and spacings of these reflections in the different models in Figure 11. Although these correlations are plausible, they are truly below the resolution of the data.

Horizon $C^{\prime}$ correlates to the boundary between Subunits $5 \mathrm{~b}$ and $5 \mathrm{c}$ at a depth of $1202 \mathrm{~m}$ (early Valanginian). It also seems to represent a transition from a sheet drape deposit below to a more ponded basin fill deposit above (Fig. 5). Yet the sedimentology of Subunits 5b and 5c are similar and do not indicate this expected facies change.

Horizon $\mathrm{C}$ is correlated with the marked change from laminated chalks to rather pure bioturbated limestones 
that occurs at the $5 \mathrm{c} / 5 \mathrm{~d}$ boundary at $1268 \mathrm{~m}$ in the upper Berriasian.

Horizon $\mathrm{D}^{\prime}$ correlates with a reversed polarity wavelet formed near the $5 \mathrm{~d} / 6 \mathrm{a}$ boundary $(1342 \mathrm{~m})$ in the Tithonian. This is the position at which there is a $20-\mathrm{m}$ transition to significantly more mudstones.

The reflection in the field data between $\mathrm{D}^{\prime}$ and $\mathrm{D}$ (Fig. 7) may correlate with a rather high impedance contrast between $6 a_{2}$ and $6 \mathrm{~b}$ at $1430 \mathrm{~m}$ (Kimmeridgian). This is the level at which limestones with very high velocity $(4.8 \mathrm{~km} / \mathrm{s})$ and low porosity $(4 \%)$ first become important (Table 2).

Horizon D correlates with the marked increase in limestone abundance in Subunit $7 \mathrm{~b}$ at $1549 \mathrm{~m}$. This correlation, identical to the Site 534 report, places D in the early Oxfordian.

\section{CONCLUSIONS}

The correlations in this chapter are based on the (1) calculation of in situ velocities from measurements of velocity, density, and porosity at the surfaces corrected using a published porosity rebound model and checked with the density logs, (2) evaluation of the uncertainty in estimates of the unrecovered lithologic section, and (3) observation of traveltime variations related to the accuracy of the relative location of the seismic data and the well.

Models 1 and 2 evaluate two possible velocity functions derived from different estimates of the lithology of the unrecovered portion in the well hole. The shaded portions between Models 1 and 2 in Figure 11 show the limits of traveltime variations related to possible errors in location of the Site. I am unable to estimate the magnitude of possible errors in the correction of the laboratory velocity data to in situ data.

The Site 534 report correlations vary significantly from those presented in this paper in placement of $C^{\prime}$, $\mathrm{C}$, and $\mathrm{D}^{\prime}$. It is not easy to analyze in detail why these correlations differ or to explain these differences on the basis of some single factor. The comparison of results can be discussed within three different domains; traveltimes, velocities, or depths. In depths the Site 534 report correlations are systematically shallower: $\beta$ by $25 \mathrm{~m}, \mathrm{C}^{\prime}$ by $48 \mathrm{~m}, \mathrm{C}$ by $72 \mathrm{~m}, \mathrm{D}^{\prime} 90 \mathrm{~m}$, and D by $2 \mathrm{~m}$. The Site 534 report placement of the reflections in the hole was not based on a velocity structure (see Table 18 in the Site 534 report) but on an approximate velocity function refined with obvious paleontological hiatuses, lithologic changes, and abrupt variations in drilling rate.

The real discrepancy between the correlations presented here and in the Site 534 report appear in the placement of $\mathrm{C}^{\prime}, \mathrm{C}$, and $\mathrm{D}^{\prime}$. Individually, the exact placement of these reflections is certainly below the resolution of the velocity model because of their close spacing. The biggest mismatch occurs in the interval $\mathrm{D}^{\prime}$ to $\mathrm{D}$ (208 $\mathrm{m}$ versus $120 \mathrm{~m}$ ), and even here the resolution is not adequate. Within the triangle the $\mathrm{D}^{\prime}-\mathrm{D}$ interval, which probably represents somewhat more variation than can be attributed to navigation errors, is 0.06 to $0.11 \mathrm{~s}$. The thickness variation between the two correlations is just slightly more than the extreme maximum time varia- tions. It is obvious that the resolution is not entirely adequate for providing significant confidence in our results. However, the fact that the Site 534 report correlations agree with the results of Site 391 nearby is not at all significant because the same assumptions were made when correlations were established for Site 391 as were made for the Site 534 report in this volume.

Perhaps the point of this investigation should be that we cannot expect unequivocal well hole to seismic reflection correlations where the seismic reflections are spaced nearly at the wavelet length, well below our resolution. Further, only after deliberate shore-based work should correlations be made. Perhaps better velocity control from improved logging tools or near-bottom or in-hole seismic experiments will be forthcoming. If not, seismic reflection correlation requirements need to be better understood and weighed in consideration with other needs in future drilling plans.

\section{ACKNOWLEDGMENTS}

We thank E. Pye of Geoquest International for providing modeling programs to SIO and Paul Henkart and Tom Birtley for programming support. George Bryan kindly provided copies of the seismic tapes. A continuing dialogue with Bob Sheridan helped in focusing this project and providing corrections to the reflections correlations. The chapter was reviewed by R. E. Boyce, W. P. Dillon, and E. L. Hamilton. This work was supported by ONR contract N0001480-C-00440.

\section{REFERENCES}

Benson, W. E., Sheridan, R. E., et al., 1978. Init. Repts. DSDP, 44: Washington (U.S. Govt. Printing Office).

Boyce, R. E., 1976. Sound velocity-density parameters of sediment and rock from DSDP drill Sites 315-318 on the Line Islands Chain, Manihiki Plateau, and Tuamotu Ridge in the Pacific Ocean. In Schlanger, S. O. Jackson, E. D., et al., Init. Repts. DSDP, 33: Washington (U.S. Govt. Printing Office), 695-729.

1980. Determination of the relationship of electrical resistivity, sound velocity, and density/porosity of sediment and rock by laboratory techniques and well logs from DSDP Sites 415 and 416 off the coast of Morocco. In Lancelot, Y., Winterer, E. L., et al., Init. Repts. DSDP, 50: Washington (U.S. Govt. Printing Office), 305-318.

Bryan, G. M., Markl, R. G., and Sheridan, R. E., 1980. IPOD Site Surveys in the Blake-Bahama Basin. Mar. Geol., 35:43-63.

Buffler, R. T., Shipley, T. H., and Watkins, J. S., 1978. Blake continental margin seismic section. Am. Assoc. Pet. Geol. Seismic Section Ser. 2.

Dillon, W. P., Sheridan, R. E., and Fail, J. P., 1976. Structure of the western Blake-Bahama Basin as shown by 24 -channel CDP profiling. Geology, 4:459-462.

Grow, J. A., and Markl, R. G., 1977. IPOD-USGS multichannel seismic-reflection profile from Cape Hatteras to the Mid-Atlantic Ridge. Geology, 5:625-630.

Hamilton, E. L., 1976. Variations of density and porosity with depth in deep-sea sediments. J. Sediment. Petrol., 46:280-300.

Hollister, C. D., Ewing, J. I., et al., 1972. Init. Repts. DSDP, 11: Washington (U.S. Govt. Printing Office).

Jansa, L. F., Enos, P., Tucholke, B. E., Gradstein, F. M., and Sheridan, R. E., 1979. Mesozoic-Cenozoic sedimentary formations of the North American Basin; western North Atlantic. In Talwani, M., Hay, W., and Ryan, W. B. F. (Eds.), Deep Drilling Results in the Atlantic Ocean: Continental Margins and Paleoenvironment. Am. Geophys. Union, Maurice Ewing Series, 3:1-57.

Klitgord, K. D., and Grow, J. A., 1980. Jurassic seismic stratigraphy and basement structure of the western Atlantic Magnetic Quiet Zone. Am. Assoc. Pet. Geol. Bull., 64:1658-1680.

Press, F., 1966. Seismic velocities. In Clark, S. P., Jr. (Ed.), Geol. Soc. Am. Mem., 97:195-218. 
Sheridan, R. E., Golovchenko, X., and Ewing, J. I., 1974. Late Miocene turbidite horizon in the Blake-Bahama Basins. Am. Assoc. Pet. Geol. Bull., 58:1797-1805.

Sheridan, R. E., Patouret, L., and Mosditchian, G., 1978. Seismic stratigraphy and related lithofacies of the Blake-Bahama Basin. In Benson, W. E, Sheridan, R. E., et al., Init. Repts. DSDP, 44: Washington (U.S. Govt. Printing Office), 529-546.

Sheridan, R. E., Windish, C. C., Ewing, J. I., and Stoffa, P. L., 1979. Stratigraphy and structure across the Blake Escarpment based on seismic reflection profiles. Am. Assoc. Pet. Geol. Mem., 29: 177-186.

Shipley, T. H., Buffler, R. T., and Watkins, J. S., 1978. Seismic stratigraphy and geologic history of the Blake Plateau and adjacent western Atlantic continental margin. Am. Assoc. Pet. Geol., 62: $792-812$.

Shipley, T. H., and Watkins, J. S., 1978. Fine-scale seismic stratigraphy in the western North Atlantic. Geology, 6:635-639.

Tucholke, B. E., 1979. Relationship between acoustic stratigraphy and lithostratigraphy in the western North Atlantic Basin. In Tuchol- ke, B. E., Vogt, P. R., et al., Init. Repts. DSDP, 43: Washington (U.S. Govt. Printing Office), 827-846.

Tucholke, B. E., and Mountain, G. S., 1979. Seismic stratigraphy, lithostratigraphy, and paleosedimentation patterns in the North American Basin. In Talwani, M., Hay, W., and Ryan, W. B. F. (Eds.), Deep Drilling Results in the Atlantic Ocean: Continental Margins and Paleoenvironment. Am. Geophys. Union, Maurice Ewing Series, 3:58-86.

Tucholke, B. E., and Vogt, P. R., 1979. Western North Atlantic: sedimentary evolution and aspects of tectonic history. In Tucholke, B. E., Vogt, P. R., et al., Init. Repts. DSDP, 43: Washington (U.S. Govt. Printing Office), 791-823.

Vail, P. R., Mitchum, R. M., and Thompson, S., 1977. Seismic stratigraphy and global changes in sea level. In Payton, C. E. (Ed.), Seismic Stratigraphy-Application to Hydrocarbon Exploration. Am. Assoc. Pet. Geol. Mem., 26:49-212.

Winterer, E. L., Ewing, J. I., et al., 1973. Init. Repts. DSDP, 17: Washington (U.S. Govt. Printing Office). 